Tyndale Bulletin 67.2 (2016) 247-268

\title{
NAME GIVING BY PAUL AND THE DESTINATION OF ACTS
}

\author{
Richard G. Fellows \\ (rfellows@shaw.ca)
}

\begin{abstract}
Summary
It is proposed that Paul gave new names to the most courageous and prominent founding members of his churches. Crispus, Jason, Lydia, and Titius Justus seem to have received the names Sosthenes, Aristarchus, Euodia, and Stephanas respectively. Epaenetus and Theophilus may also be new names. The names have meanings that reflect leadership roles and a similar cluster of leadership names in Third Corinthians witnesses to the renaming phenomenon. Acts may have been written for the Aegean believers, who already knew that Crispus was Sosthenes and that Jason was Aristarchus.
\end{abstract}

\section{Introduction}

Abram became Abraham (Gen. 17:5), Sarai became Sarah (Gen. 17:15), Jacob became Israel (Gen. 32:28), and Hoshea became Joshua (Num. 13:16). These were prominent, founding members of the nation of Israel. Similarly, some of the prominent, founding members of the Jesus movement were given new names. Matthew 16:18 famously reads, 'And I tell you, you are Peter, and on this rock I will build my church, and the gates of Hades will not prevail against it', ${ }^{1}$ and this has strong parallels with the cases of Abraham and also Augustus. ${ }^{2}$ Jesus

1 Bible translations are taken from the NRSV.

2 W. D. Davies and Dale C. Allison, Jr., A Critical and Exegetical Commentary on the Gospel According to Saint Matthew, ICC, 3 vols. (Edinburgh: T \& T Clark, 1991), 2:623-4. Octavian was nearly renamed for being a founder of the Roman people: 'For when some proposed to confer upon him the name of Romulus, as being, in a manner, a second founder of the city, it was resolved that he should rather be called Augustus' (Suetonius, The Divine Augustus 7). 
called the sons of Zebedee 'Boanerges' (sons of thunder) (Mark 3:17), and the apostles named Joseph 'Barnabas' (son of exhortation) (Acts 4:36). Ignatius was also called 'Theophorus' (bearer of God), and Hegessipus recorded that James the brother of Jesus was called 'Oblias' (bulwark of the people). ${ }^{3}$ This paper will explore whether Paul likewise gave new names to the prominent, founding, members of his congregations.

It will first be argued that Acts was written for at least some of the Aegean churches. It will then be argued that Crispus, Jason, Lydia, and Titius Justus were the leading founding members of the congregations in their cities and that they were probably given the new names Sosthenes, Aristarchus, Euodia, and Stephanas respectively. Epaenetus and Theophilus will then be added as further possible examples of the renaming phenomenon in the region. After addressing objections to the renaming theory, we will present some further evidence from Third Corinthians.

\section{The Aegean Audience of Acts}

The second half of Acts focuses on Paul, and loses interest in Peter and the Jerusalem church. It records Paul's missionary activity but says nothing about how the faith was spread to Alexandria or Rome, for example. All this is natural if Acts was written for at least some of the churches that Paul had founded. While Acts also details events that the author lived through, it seems to be largely a history of how the faith was passed down to Paul's churches. It is shaped for their interests. There is evidence that Acts was written for the churches of the Aegean in particular, or at least those of Macedonia, as we will now see. ${ }^{4}$

\subsection{Paul's Journey to Macedonia}

Acts 16:6-10 records that the Holy Spirit (16:6), the Spirit of Jesus (16:7), and God (16:9-10) had given the missionaries guidance with the purpose, apparently, of bringing them to Macedonia as soon as

3 Ignatius's salutations. Eusebius, Ecc. Hist. 2.23.

4 Those arguing for an Aegean audience include Xabier Aletheia, 'Localización de la comunidad de Lucas', EstBíb LXIX (2011), 289-300 and Craig S. Keener, Acts: An Exegetical Commentary, 4 vols. (Grand Rapids: Baker Academic, 2012-15), 1:429-34. 
possible. $^{5}$ A Macedonian audience of Acts would have been particularly interested to learn that it had been the divine will for the faith to spread to them without delay.

\subsection{Acts 16:12}

Here we propose that the honour that Luke gives Philippi in Acts 16:12 makes most sense if Theophilus was from there.

We set sail from Troas and took a straight course to Samothrace, the following day to Neapolis, and from there to Philippi, which is a leading


and a Roman colony. (Acts 16:11-12)

Acts 16:11-12 exaggerates the prominence of Philippi. Ascough writes,

Philippi is, to our knowledge, nowhere attested to as a 'first city' of Macedonia; that honour belonged to Thessalonica. Nor was Philippi the capital city of its district; that city was Amphipolis. Neither is the reference to the first Macedonian city to which Paul came, for that city was Neapolis. ${ }^{6}$

Many, including NA28 (tentatively), resolve the problem by the

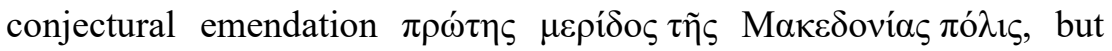
since this reading is supported by no Greek manuscripts, Witherington rightly dismisses it as 'a step of desperation'?

Ramsay, Witherington, Ascough, and Keener argue that the author is here expressing civic pride in his hometown or adopted town, in much the same way that Paul (and Luke) honour Tarsus in Acts 21:39. ${ }^{8}$ This theory should be nuanced a little. It is unlikely that Luke intended to honour himself here. Firstly, Philippi was not the author's hometown, since the first person plural occurs already in Troas (Acts 16:10). Secondly, Luke was reluctant to honour himself, since he uses the first person sparingly and usually in the plural. However, Luke may be honouring Theophilus here, just as he honours him in Luke 1:3,



5 Note that if this understanding is correct, Acts cannot be implying that Paul took an evangelistic detour to north Galatia.

6 Richard S. Ascough, 'Civic Pride at Philippi: the Text-Critical Problem of Acts 16.12', NTS 44 (1998) 93-103.

7 Ben Witherington III, The Acts of the Apostles: A Socio-Rhetorical Commentary (Grand Rapids: Eerdmans, 1998), 489.

8 William M. Ramsey, St. Paul, The Traveler and Roman Citizen, $3^{\text {rd }}$ ed. (London: Hodder \& Stoughton, 1897), 206-207. Keener, Acts, 3:2382-83. 
in the New Testament only for Felix and Festus. The audience of Acts benefitted from Theophilus's sponsorship of the work, and they would not have resented the honour that Luke gives him in Acts 16:12 or in Luke 1:3. The fact that Luke singles out Philippi for special praise therefore supports the view that it was Theophilus's town.

\subsection{Named People}

Acts names many from the Aegean region. From Macedonia we have Lydia, Jason, Gaius, Aristarchus, Sopater, Pyrrhus, and Secundus. From Achaia we have Dionysius, Damaris, Titius Justus, Crispus, Sosthenes, and Erastus. From Asia we have Tyrannus, Demetrius, Alexander, Tychicus, Trophimus, and Eutychus. By contrast, the regions evangelised on the 'first missionary journey' yield only Sergius Paulus, Elymas, Gaius (Acts 20:4), and perhaps Timothy. The large number of named individuals from the Aegean is explicable if Acts was written for that region: many of the hearers would have known many of the named people.

Macedonians are given a particular prominence. They are listed first in 20:4. Also, it seems odd that Luke introduces 'Gaius and Aristarchus, Macedonians' in 19:29 since they play no further part in the story. However, this incidental mention of Macedonians would be of interest to Luke's Macedonian audience. Similarly, 27:2 seems to give a 'shout-out' to Aristarchus, along with his hometown and home province. Luke has already written that Aristarchus is from Thessalonica (20:4), but the repetition will be pleasing to Macedonian believers.

Jason and perhaps Alexander, Tyrannus, and Pyrrhus are mentioned without introduction, as if they are already known to Luke's audience. We will see later that this raises the possibility that Luke might refer to Jason by a different name elsewhere in his text. This would create no ambiguity for those who knew Jason.

\subsection{The Author's Connections with the Region}

Lastly, the author of Acts himself seems to have spent some time in Macedonia, and perhaps in Philippi in particular. The first 'we passage' ends in Philippi (Acts 16:17) and the author does not seem to have continued with Paul to Achaia, since his name is absent from 2 Corinthians 1:19 and 1 Thessalonians 1:1. Also, he visited Philippi in 
Acts 20:6. The absence of any Philippian in Acts 20:4 suggests that Luke may have acted as the Philippians' representative.

The 'anti-Marcionite prologue' to the gospel of Luke says that this gospel was written in Achaia.

Now, if Acts was indeed written for the churches of Macedonia and Achaia, then Lydia, Jason, Titius Justus, and Crispus were probably the prominent founding members of their congregations, since it would be undiplomatic for Luke to give these people an honourable mention, while failing to mention those who actually deserved the credit.

\section{Hypothesised New Names of the Prominent Founding members of Paul's Aegean Churches}

\subsection{Crispus Sosthenes}

In this journal in $2005 \mathrm{I}$, following John Chrysostom and A. Myrou, argued that Crispus (Acts 18:8) was renamed 'Sosthenes' (Acts 18:17). ${ }^{9}$ This hypothesis makes sense of what is otherwise a very puzzling passage. Here we will merely summarise the reconstruction that results. Crispus, being an archisynagogos, was a powerful benefactor, and his conversion was followed by many others. He was then appropriately named 'Sosthenes', meaning 'saving strength', and was beaten by the Jews because of his defection to Paul's camp. He moved to Ephesus, where Paul used his endorsement of 1 Corinthians (1 Cor. 1:1) because his name carried weight in Corinth. ${ }^{10}$ Later we will discuss why Paul and Luke switch between the names 'Crispus' and 'Sosthenes'.

9 Richard G. Fellows, 'Renaming in Paul's Churches: the case of Crispus-Sosthenes revisited', TynBul 56.1 (2005), 111-30, esp. 128-130; Chrysostom, Homilies in Acts, 39, 1-2 (PG 60, 227-79); A. Myrou, 'Sosthenes: The Former Crispus (?)', GOTR 44 (14, 1999), 207-12.

$10 \mathrm{~K}$. Fulton has made the most thorough study of the phenomenon of co-senders and concludes, 'it seems likely that the recipients would have regarded those named as the senders of the letter as sharing responsibility for the message of the letter and in agreement with its contents'. Karen Fulton, The Phenomenon of Co-Senders in Ancient Greek Letters and the Pauline Epistles 218 (PhD diss., University of Aberdeen, 2011), http://ethos.bl.uk/OrderDetails.do?uin=uk.bl.ethos.542628. 


\subsection{Jason Aristarchus}

Our information on Aristarchus coincides well with that on Jason, and in no way conflicts.

Aristarchus (Acts 20:4) and Jason (Acts 17:1, 5) were Thessalonians.

Aristarchus was a Jew. We know this from Colossians 4:10-11 and from the fact that he accompanied Paul on his voyage towards Rome. To refute the charges against him, Paul needed to show that he was a loyal Jew, so to be seen with Gentile companions would have undermined his case. Jason too was a Jew. This is clear from Romans 16:21 and from his name, which was rare for Gentiles. ${ }^{11}$

Both Jason and Aristarchus were with Paul in Greece shortly before Paul's final journey to Jerusalem. Paul had originally planned to sail directly from Greece (Acts 20:2-3) so his travel companions, including Aristarchus, must have assembled there. Paul wrote Romans at this time, sending greetings from Jason. Paul left early in the travel season (Acts 20:6) and Phoebe, the carrier of Romans, could not have departed before the travel season, so it is unlikely that Aristarchus's arrival in Greece was after Phoebe had left. Paul, therefore, probably had opportunity to send greetings from Aristarchus to the church of Rome. On any hypothesis, Aristarchus was already a travel companion of Paul (Acts 19:29) so it is a little surprising that Paul does not send his greetings (unless he was Jason). Furthermore, if Jason was not Aristarchus, we do not know why he was with Paul when Romans was written. Paul had recently passed through Thessalonica (Acts 20:1-2) so it is unlikely that Jason journeyed to Corinth to consult with Paul. Nor is it likely that he travelled to deliver a message, since Aristarchus could have done that. Some may worry that the Jason of Romans 16:21 could have been a different man from the Jason of Acts, but the name is not common enough to justify much anxiety on this issue, and the renaming hypothesis has no need of such coincidences. ${ }^{12}$

Aristarchus was courageously loyal to Paul, as was Jason. Aristarchus chose to be with Paul in Ephesus at a dangerous time (Acts

11 P. M. Fraser and E. Matthews, eds., A Lexicon of Greek Personal Names vol. IIIB: Central Greece: From the Megarid to Thessaly (Oxford: Oxford University Press, $2000)$ records 43456 people, of which only $18(0.04 \%)$ are called Jason.

12 In her database of 1979 male Jews, Tal Ilan finds 13 called Jason. This is $0.66 \%$. (Lexicon of Jewish Names in Late Antiquity: Part III The Western Diaspora 330 BCE650 AD, TSAJ 126 (Tübingen: Mohr Siebeck, 2008), 61, 63). 
19:29; 1 Cor. 16:9), and he accompanied Paul to Jerusalem (Acts 20:4) and journeyed with Paul, the prisoner, towards Rome (Acts 27:2). Jason hosted Paul and other believers when there was a risk of persecution (Acts 17:5-9), so he too had courage.

Aristarchus and Jason both seem to be prominent, well-travelled believers. Aristarchus is generally ranked high in lists of names, being the first of six greeters in Colossians 4:10-14, and the second of seven men in Acts 20:4, though he is the third of five in Philemon and the last of two in Acts 19:29. At Acts 17:5 Luke mentions Jason without introduction, as if his audience already knows him. ${ }^{13}$ This, and the fact that he appears in Romans 16:21 ahead of influential people such as Gaius and Erastus, imply that he was a prominent believer, at least among the churches for which Acts was written.

In summary, Jason and Aristarchus were prominent, courageous, well-travelled, Jewish believers from Thessalonica, and we read the name 'Jason' in Romans 16:21 where we would expect to see Aristarchus, and we read 'Aristarchus' in Acts 20:4 where we would expect to see Jason.

New names were often given to prominent believers and the new name promoted the authority of the individual relative to others in the same community (Matt. 16:18-19). A writer, when choosing to honour such people, would likely afford them their new names and would list them ahead of others, especially others in their communities. Thus Peter is always named first in the lists of the twelve, and the Boanerges brothers are next in Mark 3:16-19, where their new name is given. Similarly Barnabas is the first of the five church leaders in Acts 13:1. Thus, the general prominence of 'Aristarchus', including in lists of names, raises the question of whether his was a new name.

The suspicion that Aristarchus was indeed Jason is enhanced by the fact that the name 'Aristarchus' is Greek and means something like 'best leader', which is a fitting name for this courageous, committed, church leader.

The familiarity of Luke's audience with the well-travelled JasonAristarchus goes a long way towards explaining why Acts can switch to calling him 'Aristarchus' without making the equation explicit. The phenomenon of name switching will be discussed in more detail later.

13 So, for example, Keener, Acts, 1:431 and Hans Conzelmann, Acts of the Apostles (Philadelphia: Fortress Press, 1987), 135. 


\subsection{Lydia Euodia}

It is generally agreed that Euodia and Syntyche (Phil. 4:3) were leaders of the Philippian church. It has been argued above that Luke would not have mentioned Lydia if she was not an important church leader.

There is also a consensus that Euodia and Syntyche were probably converted during Paul's first visit to Philippi. This is suggested by the fact that they had struggled alongside Paul in the work of the gospel. Lydia too was a convert of Paul's founding visit. She hosted Paul and his companions (Acts 16:14-15) and later hosted the believers (Acts 16:40).

For these reasons many have considered the possibility that Lydia was Euodia or Syntyche. Euodia is more likely than Syntyche because Paul names her first, which suggests that she was the more prominent leader. While commentators suggest that Lydia may have been a nickname (one from Lydia), they have overlooked the possibility that Paul gave the name 'Euodia' to Lydia. There is some evidence for this.

The names $\Lambda v \delta i ́ \alpha$ and Ev̉odía have a degree of phonetic similarity, and this increases the probability of identity (compare Saul-Paul, SilasSilvanus, Jesus-Justus, Joseph-Justus). ${ }^{14}$

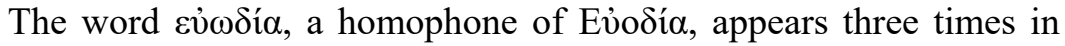
the New Testament (2 Cor. 2:15; Eph. 5:2; Phil. 4:18). Phil. 4:18

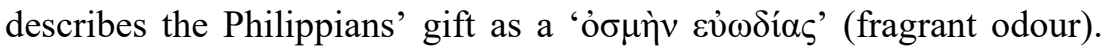
More intriguing still is 2 Corinthians 2:15 where Paul describes himself and his co-workers as 'the aroma ( $\left.\varepsilon \dot{v} \omega \delta^{\prime} \alpha\right)$ of Christ to God among those who are being saved'. Since the hypothesised Lydia-Euodia had opened her home for others to hear the gospel and had 'struggled beside me in the work of the gospel', Paul would surely have included her among his co-workers who were 'the aroma of Christ to God among those who are being saved'. It is therefore possible that Paul named Lydia 'Ev̉ooí $\alpha$ ' with a thought such as that in 2 Corinthians 2:15 and/or Philippians 4:18 in mind. The name Ev̉ $\omega \delta$ ía would work as a new name because its homophone, Eủodía, was a recognised name.

\subsection{Gaius Titius Justus Stephanas}

In an excursus in my paper on Sosthenes, I proposed that Stephanas (1 Cor. 1:16; 16:15-18) was a new name for Titius Justus (Acts 18:7) or

14 For other examples of this phenomenon see R. Bauckham, Gospel Women: Studies in the Named Women in the Gospels (Grand Rapids: Eerdmans, 2002), 181-85. 
indeed for Gaius Titius Justus if the Gaius of Romans 16:23 and 1 Corinthians 1:14 is to be equated with Titius Justus. ${ }^{15}$ I made the following points:

1) The church of Corinth started with the conversion of the household of Stephanas, and Acts gives this role to Titius Justus.

2) $\Sigma \tau \dot{\varepsilon} \varphi \alpha v o \varsigma$ is a Pauline term (1 Cor. 9:25; Phil. 4:1; 1 Thess. 2:19) so it would not be surprising for Paul to give him a related name.

3) 'The household of Stephanas appointed themselves to the service of the saints and this is just what we might expect Paul to write about the household of Gaius/Titius Justus, that had played host to Paul and/or the church.'

4) The equation of Stephanas with Gaius would explain the absence of the name 'Stephanas' from the list of greeters in Romans 16:21-23.

These points can be enhanced with further arguments.

\subsubsection{Firstfruits of Achaia}

Paul describes the household of Stephanas as 'firstfruits of Achaia'. This does not mean that they were the very first converts in Achaia (Dionysius and Damaris of Athens were earlier converts). Rather, the term implies that their conversions were early and led to many others in Corinth and beyond. This fits Titius Justus. His house adjoined the synagogue, so visitors to the synagogue could be invited to this house to hear Paul's message. It was 'an ideal venue for harvesting Gentile God-fearers' ${ }^{16}$ Such visitors would include people from elsewhere in the province, so the faith could spread from this house to the rest of Achaia. The household of Titius Justus were likely the firstfruits, not only of Corinth, but of Achaia, and this is exactly what we are told about the household of Stephanas.

\subsubsection{Why Did Stephanas, Fortunatus, and Achaicus Travel to Ephesus?}

If Stephanas was not the host of the church it is not clear why he and his two companions travelled to Ephesus to visit Paul. The journey cost about two hundred days' wages for a labourer and exposed three people to the risk of shipwreck. ${ }^{17}$ The delivery of the Corinthians' letter

15 Fellows 'Renaming', 2005. For the equation of Gaius with Titius Justus see Edgar J. Goodspeed, 'Gaius Titius Justus', JBL 69.4 (1950), 382-83.

16 William J. Larkin, Acts, IVPNTC (Downers Grove, IL: InterVarsity, 1995), 264.

17 ORBIS, http://orbis.stanford.edu/\#mapping. Matt 20:2. 
would not have required three people. Furthermore, the Corinthian church was disunited and many of them were not in Paul's camp, so there would not have been a consensus behind funding the trip.

If, on the other hand, the household of Stephanas hosted the church meetings, then an explanation for the journey is readily at hand. When they came together as a church (1 Cor. 11:17-18), some ate and became drunk, while others went hungry (11:21), and this humiliated those who had nothing (11:22). It is unlikely that the hosts of the meeting were among the greedy people, for Paul writes, 'Do you not have homes to eat and drink in?' (11:22), and 'If you are hungry, eat at home' (11:34). If the hosts were among those setting a bad example, they would have replied 'but we are at home!' 18 The hosts were not to blame, so we can infer that they were unable to control the behaviour at the meetings. The hosts' loss of control neatly explains the divisions in the church, and it also explains why such a large section of 1 Corinthians (chapters 11-14) concerns behaviour during the church's meetings. Paul discusses church meetings in no other letter.

Stephanas's motive for making the expensive journey to Ephesus now comes into focus: his household hosted the church and they had recently lost control of the meetings so they travelled to Ephesus (at Stephanas's expense) to get Paul's endorsement. This is the most economical explanation for why three members of the same household visited Paul in Ephesus, at great expense, at this time, and received his backing. It is less likely that Stephanas hosted only one of a plurality of 'house-churches' in Corinth, since this would not easily explain why Paul commends his household to the whole church, and the letter does not discuss meetings of such sub-groups. ${ }^{19}$

18 Edward Adams, The Earliest Christian Meeting Places, LNTS 450 (London: T\&T Clark, 2013), 29.

19 The importance of sub-group meetings has been greatly over-estimated. E.A. Judge, Social Distinctives of the Christians in the First Century: Pivotal Essays by E.A. Judge, ed. D. M. Scholer (Peabody, MA: Hendrickson, 2008), 25, is probably correct to suggest that the phrase 'church in their house' refers to gatherings that consisted of little more than the members of the particular household. The assembly in the house of Prisca and Aquila send greetings to the Corinthian church precisely because they had lived in Corinth and therefore knew the Corinthian church intimately (1 Cor. 16:19). Similarly Paul greets them in Rom. 16:3-5 because he knew them from their time in Ephesus. 


\subsubsection{I urge you...}

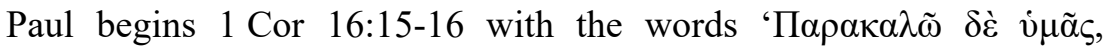
$\alpha \dot{\delta} \varepsilon \lambda \varphi$ of' $^{\prime}$ (I urge you, brothers and sisters). The 'awkwardness of vv. $15-16$ ', as Fee describes it, is that only in 16:16 do we learn what he is urging them to do. ${ }^{20}$ Did Paul really expect his readers to hold all of 16:15 in their minds and interpret it in the light of the appeal, which they learned only upon hearing 16:16? This delay in explaining the action that he wants them to take is explicable if they already knew. If the Corinthians had disregarded the authority of their hosts, the household of Stephanas, then they would have known the nature of Paul's appeal, at least in broad terms, as soon as they heard the name 'Stephanas', and the structure of 16:15-16 would not be awkward for them.

\subsection{4 'they have devoted themselves to the service of the saints'}

A reason why the Corinthians should submit to the household of Stephanas is that 'they have devoted themselves to the service of the saints' (1 Cor. 16:15b). What kind of service is Paul referring to here? If it was the kind of service that the other church members were equipped to perform, then Paul is here implying that his target audience had not devoted themselves to the service of the saints. Such an argument would be uncharacteristic of Paul, who tends to praise those he tries to reform. If, on the other hand, the service implied here is the service of hosting the church meetings, and if the church met only in the house of Stephanas, and no-one in the audience had suitable property for hosting the church, then the reference is to a type of service that only they were in a position to perform. Paul's words then have no accusatory insinuation and are more Pauline. Paul would then be comparing this household's commitment to service with GrecoRoman patrons who, in a similar position, would likely laud it over their clients.

If Gaius Titius Justus was not Stephanas, and if Crispus was not Sosthenes, then Gaius, Titius Justus, Crispus, and the believing members of their households were, presumably, among the audience of 1 Corinthians. Such a group would have constituted a large fraction of the total Corinthian church. How would they have understood 1 Corinthians 16:16-18 where Paul urges them to submit to the

20 Fee, The First Epistle to the Corinthians (Grand Rapids: Eerdmans, 1987), 828. 
household of Stephanas? 1 Corinthians 16:15a would have been ineffective in persuading them, since they too were 'firstfruits'. 1 Corinthians 16:15a works best if the household of Stephanas had an unambiguously unique claim to be the 'firstfruits'. Welborn puts it well: 'Paul's demand that the Corinthians "submit" or "be subject" to Stephanas and his household is surprising, if not to say stunning, in context. Why should the other Corinthian Christians, and especially the leaders of other house-churches, men of substance such as Crispus and Gaius, subordinate themselves to Stephanas?'21 Welborn's problem is resolved when we see that Stephanas was Gaius, and Crispus was Sosthenes, who was no longer in Corinth (1 Cor. 1:1).

\subsubsection{The Name 'Stephanas'}

The name Stephanas is very rare. In the seven volumes of Lexicon of Greek Personal Names published so far, there are just six people called Stephanas. This represents just $0.002 \%$ of all recorded persons. The same database records just eight cases of 'Stephanephoros'. 'Stephanas' is either an abbreviation of 'Stephanephoros', or it is a more direct extension of 'Stephanos'. It therefore means 'crowned' or 'crown-bearer', or the like. Stephanephoroi were civic magistrates/priests who wore a crown and received their position through benefaction. In New Testament times crowns were given as civic honours to luminaries because of their beneficence or achievements on behalf of the city. ${ }^{22}$ In inscriptions the most commonly mentioned response of the community to a benefaction is the giving of a crown. ${ }^{23}$ Inscriptions found at Delos (twice), Egypt, Asia Minor, and Berenice (twice) show that synagogues likewise gave crowns to their benefactors, including those who financed building construction. ${ }^{24}$ The name 'Stephanas' is therefore very appropriate for

21 Larry L. Welborn, An end to enmity: Paul and the 'wrongdoer' of second Corinthians, BZNW 185 (Berlin: De Gruyter, 2011), 254.

22 See J. R. Harrison, 'The Fading Crown: Divine Honour and the Early Christians', JTS 54.2 (2003), 493-529.

23 Frederick W. Danker, Benefactor: Epigraphic Study of a Graeco-Roman and New Testament Semantic Field (St. Louis, MO: Clayton, 1982), 468, writes, 'the most frequently mentioned [award for benefaction] is the crown'. The awarding of crowns is mentioned in docs 1, 3, 12, 16, 17, 19, 20, 21, 23, 33, 34, 39, 43, 44, and 48 .

24 For Delos and Egypt see Donald D. Binder, 'Second Temple Synagogues', http://www.pohick.org/sts/index.html. It is disputed whether the Egypt inscription concerns Jews. For Asia Minor see CIJ 738. For Berenice see Marcus Tittius in J. Reynolds Excavations at Sidi Khrebish Benghazi (Berenice). Voume I: Buildings, coins, inscriptions, architectural decoration, edited by, J.A. Lloyd. Supplements to 
someone who gave space in his house for the use of the church. This suggests that he may have been given this name/title in recognition of his benefaction.

The suspicion that 'Stephanas' and 'Sosthenes' are names/titles that were given by Paul or the church is enhanced by the fact that they are Greek. It is unlikely that both had Greek birth names since we know nine names of members of the Corinthian church and all but one of them is Latin or Latinised, including Stephanas's household members, Fortunatus, and Achaicus. ${ }^{25}$

Finally, Conzelmann and others judge Luke 'unreliable' on the basis of the absence of the name 'Stephanas' in Acts. ${ }^{26}$ This problem is solved if he was Titius Justus.

\subsection{Epaenetus}

Apart from the household of Stephanas, the only other person whom Paul describes as 'firstfruits' is Epaenetus, the 'firstfruits of Asia'

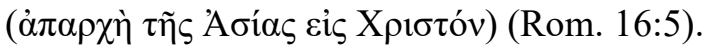

He may therefore have provided a similar role to Stephanas. He is the third of 27 in the list of those greeted in Romans 16, so he was probably a prominent believer. Was he the recipient of a new name? The name 'Epaenetus' means 'praised/commended' and it is surely no coincidence that it, like 'Stephanas', belongs to the semantic field of benefaction and is part of Paul's vocabulary ( $\dot{\pi} \pi \alpha v \varepsilon \dot{\varepsilon} \omega$ : Rom. 15:11;


8:18; Phil. 1:11; 4:8; Eph. 1:6, 12, 14). There are numerous inscriptions in which beneficiaries agree to 'praise' a benefactor, and Romans 13:3 also appears to use the term in connection with benefactions. ${ }^{27}$ The name 'Epaenetus' therefore supports the view that Paul's 'firstfruits' were given new names in recognition of their benefaction to the church.

Libya Antiqua 5. Libya: Department of Antiquities, Ministry of Teaching and Education. People's Socialist Libyan Arab Jamahiriya. 1977:244-45, no. 17 = Roux and Roux 1949 = IGRI 1024, and also Decimus Valerius Dionysius in SEG vol.16, no. 931.

25 Prisca, Aquila, Titius Justus, Gaius, Crispus, Fortunatus, Achaicus, Tertius, and Erastus (the only purely Greek name).

26 Conzelmann, Acts, 152.

27 See Bruce W. Winter, Seek the Welfare of the City (Grand Rapids: Eerdmans, 1994), 35-36. 
The connection between benefaction and the names 'Stephanas' and 'Epaenetus' is illustrated by an inscription from ca. $24 \mathrm{CE}$, in which a synagogue community honours a benefactor:

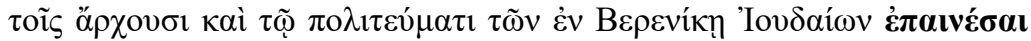

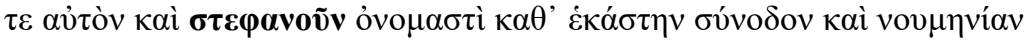

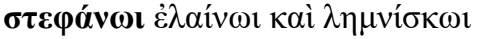

the leaders and the politeuma of Judeans in Berenike decided to praise him, to crown him by name at each gathering and new moon with a crown of olive branches and ribbon, ... 28

Also consider the Junia Theodora inscriptions. She was contemporary with Titius Justus and had much in common with him. She was a resident of Corinth, a Roman citizen, and she was commended for hosting visitors. The 84 lines of the inscriptions repeatedly resolve to praise her and crown her, using the words $\dot{\varepsilon} \pi \alpha v \dot{\varepsilon} \omega$ and $\sigma \tau \dot{\varepsilon} \varphi \alpha v o \varsigma$ five times each. ${ }^{29}$

\subsection{Other Possible Founding Benefactors}

Prisca and Aquila (Rom. 16:5; 1 Cor. 16:19), Nympha (Col. 4:15), and Philemon (Phlm. 1:2) had assemblies in their houses but such gatherings may have consisted of little more than members of their own households. ${ }^{30}$ There is no evidence that they were founding benefactors of the importance of those discussed above. Paul has to cajole Philemon with every rhetorical tactic, so Philemon was not a committed loyal convert. It is therefore hard to imagine why Paul would want to endorse Philemon's authority by giving him a new name. Prisca, Aquila, and Nympha were probably not converts of Paul directly, so Paul may not have felt entitled to give them new names. So, it is true that the names Prisca, Aquila, Nympha, and Philemon do not have meanings that are suggestive of leadership roles, but we cannot be sure that any of these individuals were new-name-worthy, and nor can we be sure that they did not have new names that are unknown to us.

28 Joyce Reynolds, Excavations at Sidi Khrebish Benghazi (Berenice), vol. 1: Buildings, Coins, Inscriptions, Architectural Decoration, ed. J. A. Lloyd, Libya Antiqua Sup 5 (Libya: Dept. of Antiquities, Ministry of Teaching and Education, People's Socialist Libyan Arab Jamahiriya, 1977), 244, no. 17. Translation by Philip A. Harland, Associations, Synagogues, and Congregations (Minneapolis: Fortress, 2003), 225.

29 R. Kearsley, 'Women in Public Life in the Roman East: Iunia Theodora, Claudia Metrodora and Phoebe, Benefactress of Paul', TynBul 50.2 (1999), 189-211.

30 See note 19. 
Phoebe (Rom. 16:1-2), was an important benefactor of the church of Cenchreae, but we do not know whether she was its founding benefactor. Her name means 'bright', and it is not clear whether this would work as a new name.

Carpus (2 Tim. 4:13) may have been Paul's host in Troas. Was he, like Gaius (Rom. 16:13), host to the church as well as to Paul? While his name, meaning 'fruit', was common, it is one of only a few New Testament names that are part of Paul's vocabulary, and it might work as a new name.

\subsection{Theophilus}

It has been argued above that Theophilus sponsored Luke's works and was a member of one of Paul's Aegean churches, probably Philippi. The meaning of his name, 'Friend of God' or 'Lover of God', makes it plausible this was a new name that was given to him in response to material support that he had given to the church. Some further considerations support this possibility:

Plutarch writes, 'Hence those kings who were unwilling to be proclaimed a god or son of a god, but rather Philadelphus or Philometer of Euergetes or Theophiles, were ungrudgingly honoured by those who gave them these noble yet human titles. ${ }^{31}$ Plutarch lists the name/title 'Theophiles' alongside 'Euergetes' (benefactor).

A closely related name, Philotheos, was used as a name or title for Akeptous, a benefactor honoured in a mosaic in the church of Megiddo, probably in the third century. ${ }^{32}$

Luke calls Theophilus кpó $\tau 1 \sigma \tau o \zeta$ (most excellent), implying that Theophilus was a high ranking official. Luke uses the same term elsewhere only for the governors Felix (Acts 23:26; 24:3) and Festus (26:25), both of whom had exclusively Latin names. It would be a little surprising for Luke's dedicatee to have a Greek birth name, especially if he was a resident of Philippi, which was a Roman colony. Indeed, Keener writes "Theophilus" is probably not Philippian, since most persons of status there would probably go by their Roman names'. ${ }^{33}$

31 Plutarch, Moralia 543.

32 Yotam Tepper and Leah Di Segni, A Christian Prayer Hall of the Third Century $A D$ at Kefar 'Othnay (Legio) (Jerusalem: The Israel Antiquities Authority, 2006), 3642.

33 Keener, Acts, 1:431. 
Keener's problem is solved if Theophilus was a new name and not his birth name.

\subsection{Recap and Naming Patterns}

Luke names four people who seem to be founding benefactors of Paul's churches in Achaia and Macedonia (Crispus, Titius Justus, Jason, and Lydia). We have seen that each of them has an identical twin - someone who has coinciding biographical information and no differentiating information. Epaenetus was probably also a founding benefactor. All five are shown in the table below. Theophilus is added to the bottom of the table as a later benefactor. It is striking that three of the six people $(50 \%)$ have names that are closely related to Paul's vocabulary (Stephanas, Euodia, Epaenetus). This is significant because the vast majority of names are not part of Paul's known vocabulary. Other than our six names, there are some 66 Greek names in the New Testament. These include 'Peter' which was a new name, and 'Carpus', which may have been a new name given by Paul (see above). Of the remaining 64 names only five $(8 \%)$ are closely related to Paul's vocabulary (Stephen, Aeneas, Timon, Philemon, and Apollos).

\begin{tabular}{|c|c|c|c|c|c|}
\hline $\begin{array}{l}\text { Birth } \\
\text { name }\end{array}$ & $\begin{array}{l}\text { Hypothesised } \\
\text { new name }\end{array}$ & $\begin{array}{l}\text { Meaning of } \\
\text { new name }\end{array}$ & $\begin{array}{l}\text { In Paul's } \\
\text { vocabulary? }\end{array}$ & $\begin{array}{l}\text { List with the } \\
\text { new name }\end{array}$ & $\begin{array}{l}\text { Place in } \\
\text { the list }\end{array}$ \\
\hline Crispus & Sosthenes & Saving strength & No & - & - \\
\hline Gaius / & Stephanas & Crowned & Yes & 1 Cor $16: 17$ & $1^{\text {st }}$ of 3 \\
\hline \multicolumn{6}{|l|}{ Titius } \\
\hline \multicolumn{6}{|l|}{ Justus } \\
\hline Jason & Aristarchus & Best leader & No & Col 4:10-14 & $1^{\text {st }}$ of 6 \\
\hline Lydia & Euodia & Fragrance? & Yes & Phil 4:2 & $1^{\text {st }}$ of 2 \\
\hline$?$ & Epaenetus & Praised & Yes & Rom 16:3-15 & $3^{\text {rd }}$ of 27 \\
\hline ? & Theophilus & Friend of God & No & - & - \\
\hline
\end{tabular}

It is notable that all six have Greek names, especially as we would expect Theophilus, Sosthenes, and Stephanas to have had Latin names. Furthermore, all these Greek names have appropriate meanings. Luke is consistent in giving the likely birth name in his account of the initial evangelisation of the region.

We have also seen that the hypothesised new names tend to be prominent in the lists of names where they appear, and this lends further support to the renaming hypothesis. 


\subsection{Name switching}

Craig Keener considers the Crispus-Sosthenes hypothesis to be 'unlikely', asking 'why would Luke change names without an explanation connecting them? (That Paul likewise uses both names reinforces the objection.) ${ }^{\prime 34}$ As far as I know, this is the only objection that has been made to the theory. The same objection can be marshalled against the Jason-Aristarchus theory since Luke uses both names in the same text. Furthermore, if Stephanas was Gaius, as well as Titius Justus, then Paul calls the same man 'Gaius' at 1 Corinthians 1:14 and 'Stephanas' elsewhere in the same letter.

Should we be surprised that one person is given different names in different places in the same text, or is this practice well attested in the ancient world? This question is answered, in part, by Allison, who cites the switch between 'Jacob' and 'Israel' in the Testament of Jacob and in Joseph and Asenath 22:2; 'Peter' and 'Simon' in Mark 14:37 and Luke 22:31-34; 'Peter', 'Simon', and 'Simeon' in Acts; 'John' and 'Mark' in Acts; 'Jesus' and 'Christ' in Paul's letters; as well as the switch between 'Cephas' (Gal. 1:18; 2:9, 11, 14) and 'Peter' (Gal. 2:7, 8 ) in Galatians. ${ }^{35}$ Thus, both Paul and Luke were switchers of names. A comprehensive study of the phenomenon of name switching is lacking, but an analysis of Cicero's practice is made possible by the publication of onomasticons. ${ }^{36}$ I counted 312 occasions when Cicero mentions a person by one name and, in the next naming of the same person in the same text, uses a completely different name, without even an initial of a praenomen in common between the two references. In 87 of these cases the name switch occurs with fewer than 36 intervening words. 58 switches involve a praenomen, yet the works of Cicero contain not a single example of someone who had a Latin praenomen as his only name. ${ }^{37} 94$ of the switches involve an agnomen (honorific new name). ${ }^{38}$

\footnotetext{
34 Keener, Acts, 3:2320, 3:2749.

35 Dale C. Allison, 'Peter and Cephas: One and the Same', JBL 111 (1992), 491-92.

36 D. R. Shackleton Bailey, Onomasticon to Cicero's Speeches, 2nd ed. (StuttgartLeipzig: Teubner, 1992); Onomasticon to Cicero's Letters (Stuttgart-Leipzig: Teubner, 1995); Onomasticon to Cicero's Treatises (Stuttgart-Leipzig: Teubner, 1996).

37 Sextus-Aebutius (Pro Caecina 95-103); Publius-Africanus (De Republica 6); TitusAlbucius (Fin. 1.9); Titus-Pomponius-Atticus (De Legibus throughout; Att. 1.12; 2.9; 2.12; 2.16; 9.6; Brutus 292); Decimus-Brutus (Att. 15.10); Marcus-Brutus (Orat. 2.224); Lucius-Cicero (De Finibus 5); Quintus-Cicero (Att. 6.1); Publius-ClodiusPulchellus (Att. 2.19; 2.22; 4.3); Sextus-Cloelius (De Domo Sua 47-50); QuintusCornificius (Fam. 12.25); Titus-Flamininus (De Senectute 1); Quintus-Hortensius
} 
Most of the name switches are surprising to the modern ear and, perhaps for this reason, many of them are not preserved by English translations. Often the name switches seem to be merely for variety, but more often, perhaps, the switch occurs when the new context demands a name that differs in formality to the one already used.

The case of Gnaeus Pompeius Magnus illustrates the contexts in which one would use an honorific new name (agnomen). Pompey had been honoured with the name 'Magnus' after his victories in Africa (Plutarch, Life of Pompey 13). For Cicero, the name 'Magnus' signified high honour. ${ }^{39}$ Adams writes, "when his support for Pompey was at its most fervent, Cicero does indeed use Magnus (Att. 1:16:11, 1:16:12, 1:20:5, 2:13:2, Pro Archia 24) '. ${ }^{40}$ Conversely, a writer would avoid the use of an agnomen to deny honour to the person in question. Cicero writes that Publius Rullus will address Pompey as 'Gnaeus Pompeius' and states, 'I do not suppose that he will add "Magnus"; for it is not likely that he will grant him by a word that dignity which he is endeavouring to diminish' (Agr. 2:53). Similarly, Gracchus states his reluctance to call his enemy, L. Piso, by his agnomen, Frugi (Cicero, Pro Fonteio 39). If 'Sosthenes', and 'Stephanas' were indeed agnomina, we should expect Paul to use these names in contexts where his purposes are served by boosting the authority of the individual, and we should also expect him to avoid these names in contexts where he wants to down-play the authority of the man. This is indeed what we find. Paul uses 'Sosthenes' (but never a praenomen) when naming his co-senders, whose function is to endorse the contents of the letters. ${ }^{41}$ Similarly, we should not be surprised that Paul uses the name 'Stephanas' in 1 Corinthians because he writes, in part, to enhance Stephanas's standing in the Corinthian church. At 1 Corinthians 1:14, on the other hand, Paul is playing down the significance of being baptised by him personally. In this context honouring Crispus and Gaius with their agnomina would have undermined his purpose. In any

(Verr. 5.174-179); Gnaeus-Pompeius-Magnus (Att. 1.16; 6.1; 9.1; 9.7; 9.10); Mummius-Spurius (Rep. 3.46-47); Publius-Vatinius (Fam. 1.9).

38 In references to the frequently mentioned Gnaeus-Pompeius-Magnus, TitusPomponius-Atticus, Scipio-Africanus, and Scipio-Aemilianus-Africanus (who also earned the name 'Africanus' (Rep. 6.10)).

39 Att. 2.13.2; 8.6.2; and Att. 6.1.22 in light of In Pisonem 6-7.

40 J. N. Adams, 'Conventions of Naming in Cicero', The Classical Quarterly New Series 28 (1978), 145-166, esp. 161.

41 See note 10. 
case the names 'Crispus' and 'Gaius' are appropriate at 1 Corinthians 1:14 because it concerns a time before the new names were given.

Paul's name switching will have created no ambiguity for his audience, since they knew, ex hypothesi, that Sosthenes was Crispus, and that Stephanas was Gaius. Is it surprising that Luke does not explicitly equate Crispus with Sosthenes or Jason with Aristarchus? It has been argued above that Luke's audience were members of Aegean churches who already knew Jason. If so, they may well have known that Jason was Aristarchus. In any case Luke's purposes would not have been hindered if a reader failed to link Aristarchus to Jason. Crispus-Sosthenes would have been a very influential church leader, who had spent more time with Paul than any other believer from the region. It would not be surprising if he were well-known to the intended audience. Also, Luke's audience would have been very familiar with Paul's practice of giving new names to the founding benefactors of his Aegean churches if the phenomenon was as widespread as the data suggest. Such an audience, aware of Paul's renaming practice, and conscious of the meaning of names, would have little difficulty realising that Sosthenes was the aforementioned Crispus, as John Chrysostom later did. A close parallel is found in the case of Bar Jesus, who was also known as Elymas. Luke expects his readers to realise that the same person is intended though he does not explicitly link them. He merely repeats the title ' $\mu$ ó $\gamma o \varsigma^{\prime}$ ' in much the same way that he repeats the title ' $\alpha \rho \chi 1 \sigma v v \alpha$ ' Sosthenes.

Praenomina were used among intimate friends and family. ${ }^{42}$ Publius (Acts 28:7-8) had been such a gracious host to Paul and Luke that they had come to know him by his first name. ${ }^{43}$ Gaius was also Paul's host and Paul may have called him by his praenomen for the same reason.

42 Eleanor Dickey, Latin Forms of Address: From Plautus to Apuleius (Oxford: Oxford University Press, 2002), 63.

43 R. C. H. Lenski, The Interpretation of the Acts of the Apostles 15-28 (Augsburg Fortress, 2008, 1103, notes "'Publius" was his praenomen, and its use by Luke in place of the cognomen may indicate the intimate relation with the man into which Paul and his companions came'. 


\section{Third Corinthians}

Outside of the New Testament, the earliest reference to any of our six hypothesised new name recipients is perhaps the pseudonymous text, known as Third Corinthians, which is part of the Acts of Paul, which belongs to the second century. It contains a letter from the Corinthians:

Stephanas and the presbyters who are with him, Daphnus, Eubulus, Theophilus and Xenon, to Paul <their brother> in the Lord, greeting. Two men are come to Corinth, named Simon and Cleobius, who pervert the faith of many through pernicious words, which thou shalt put to the test. For never have we heard such words, either from thee or from other [apostles]. ${ }^{44}$ (Emphasis mine.)

The letter then proceeds to list the false doctrines of the two intruders. The author of this text discredits those doctrines by citing an unusually large number of co-senders, who serve as witnesses to the fact that the doctrines were never spoken by Paul. The author achieves his aim if he can imply that the co-senders of the Corinthians' letter were not late converts on the periphery of the church, but were the church's founding benefactors and hosts, who were present for Paul's preaching from the beginning, and had been endorsed by him. He does this, I suggest, by his selection of names. Snyder writes, 'it is interesting that all the names, including Theonoe's at 3 Cor. 2:8, may be etymologized for positive attributes' ${ }^{45}$ Close inspection shows that the names are appropriate for church leaders, and particularly for church benefactors. Stephanas (crowned) was a 'firstfruits', and we have argued that his household hosted the church. Daphnus means Laurel, which was one of the materials used to make crowns. Eubulus means 'good councillor' or 'well counselled', and Eubula was a host and benefactor in the Acts of Peter (APt 17). We know little about the Eubulus of 2 Tim. 4:21, but the author of 3 Corinthians may have considered (rightly or wrongly) that Paul had given him the name because he is mentioned first in the list of four greeters. Theophilus has already been discussed. Xenon here may mean host, as it does in Rom. 16:23. The five names are closely related in their meanings and/or associations. Furthermore, all the names except Daphnus have a degree of connection to Paul's

44 The principal witness is Papyrus Bodmer X, and this translation is from Wilhelm Schneemelcher and Robert McLachian Wilson, New Testament Apocrypha: Vol 2 (Louisville, KY: Westminster John Knox, 2003), 254.

45 Glenn E. Snyder, Acts of Paul: Formation of a Pauline Corpus, ed. Jorg Frey (Tübingen: Mohr Siebeck, 2013), 153. 
known vocabulary. ${ }^{46}$ All this demands an explanation. The author's choice of names makes perfect sense if he expected his readers to realise that these were the kinds of names that Paul gave to honour founding benefactors of the churches. It is highly unlikely that this cluster of Greek names with suitable meanings is coincidental. Only about $15 \%$ of Greek names from the Aegean in this period have meanings that might work well as leadership names in Paul's churches. ${ }^{47}$

This is confirmed by the author's use of the name 'Theonoe' just a few lines later: 'For we believe, as it has been revealed to Theonoe, that the Lord has delivered thee out of the hand of the lawless one'. The name is rare but was given to another prophetess in Euripides' Helen. She was 'called Eido in her infancy', but 'renamed Theonoe; for well she knew whatever the gods design, both present and to come'. Similarly, Plato discusses 'Theonoe' as a name for Athena. He interprets it to mean 'she who knows divine things' or 'divine intelligence'. ${ }^{48}$ It seems, therefore, that the author of 3 Corinthians casts Theonoe as a prophetess who has been recognised with an appropriate new name.

\section{Conclusions}

The founding benefactors of Paul's churches devoted themselves to the service of the saints (1 Cor. 16:15), laboured among them (1 Thess. 5:12), struggled alongside Paul (Phil. 4:3) and risked mob violence (Acts $17: 5 ; 18: 17 ; 19: 29$ ). It is not surprising, then, that Paul commended them by letter and by giving them new names. The new names will have boosted their authority in their congregations, and encouraged them to continue to live up to the names. ${ }^{49}$

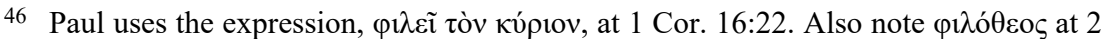

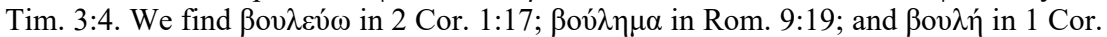
$4: 5$, for example.

47 Search the LGPN database (http://clas-lgpn2.classics.ox.ac.uk) for names in the Aegean provinces from Paul's time there.

48 Plato, Cratylus 407b.

49 The new names are compliments, and the compliments that Paul gives to his readers are invariably designed to encourage them. See Ivar Vegge, 2 Corinthians $-a$ Letter about Reconciliation, WUNT II 239 (Tübingen: Mohr Siebeck, 2008).
} 
While no one case of name giving can be proved with mathematical certainty, the renaming hypothesis as a whole is supported by the fact that Paul's founding benefactors

1) include four people who have 'doppelgängers';

2) have Greek names that have appropriate meanings and are often part of Paul's vocabulary.

The letter to Paul in so-called 'Third Corinthians' is co-sent by a cluster of benefactor names and is a witness to the renaming phenomenon. It is not so surprising that Luke switches between different names for the same people, especially if, as has been argued, Acts was written for the Aegean believers, who could have known the people concerned.

While some of the evidence rests on Acts, much of it does not. For example, the cluster of Pauline names, Epaenetus, Stephanas, Euodia, and Carpus, are found in the letters. The hypothesis removes objections to equating the Jason and the Sosthenes of Acts with the Jason and the Sosthenes of Paul's letters. This suggests that Luke did not invent these names. The phonetic similarity between Lydia and Euodia similarly supports Luke's accuracy. As we have seen, Luke can no longer be judged unreliable for not having mentioned Stephanas. 